\title{
Intellectual property: search of the optimum model of legal protection
}

\section{Інтелектуальна власність: пошук оптимальної моделі правового захисту}

Received: February 21, 2021

Accepted: April 26, 2021

\begin{abstract}
In the conditions of informatization of social processes and their globalization, the most important common basement and the engine of economic welfare of citizens is knowledge. The value of knowledge for the development of the state and society is confirmed in the Association Agreement, signed by Ukraine and the European Union, that describe the specific tasks for achieving the proper and effective level of protection and protection of intellectual property rights. The implementation of these tasks at the state level regarding the issues of legal protection of intellectual property is already taking place, but the implemented measures are caused controversial attitudes in society about their effectiveness.

The reason for such a society's assessment of the state of legal protection of intellectual property lies, first of all, in insufficient scientific and legal development of interdisciplinary problems of legal protection of intellectual property considering modern conditions of informatization of society and globalization of this process with the justification of approaches to constructing an optimal model of such protection within the legal system of our country. The scientific work, which is proposed for the reader's attention, is devoted to consideration of the mentioned problem.
\end{abstract}

Key words: intellectual property, legal protection, property, property of information.
Анотація

В умовах інформатизації суспільних процесів та їх глобалізації найважливішим загальновизнаним підгрунтям i двигуном економічного благополуччя громадян $\epsilon$ знання. Підтверджується значення знань для розвитку держави й суспільства в Угоді про асоціацією, підписаною Україною й Свропейським Союзом, 3 окресленням конкретних завдань для досягнення належного та ефективного рівня охорони i захисту прав інтелектуальної власності. Реалізація цих завдань на державному рівні стосовно питань правової охорони інтелектуальної власності вже відбувається, однак запроваджувані заходи викликають неоднозначне ставлення в суспільстві щодо їх ефективності.

Причина такої оцінки суспільства до стану правової охорони інтелектуальної власності криється, у першу чергу, у недостатній науковоправовій розробці міждисциплінарних проблем правової охорони інтелектуальної власності 3 урахуванням сучасних умов інформатизації суспільства та глобалізації цього процесу 3 обгрунтуванням підходів до побудови оптимальної моделі такої охорони в межах правової системи нашої країни.

Наукова робота, що пропонується для ознайомлення читачу, присвячена розгляду зазначеної проблематики.

Ключові слова: інтелектуальна власність, правова охорона, власність, власності на інформацію.

\footnotetext{
${ }^{44}$ Doctor of Law, Proffessor, professor at the Criminal Law Department, Yaroslav Mudryi National Law University, Kharkiv, Ukraine.

${ }^{45} \mathrm{PhD}$ of Law, Yaroslav Mudryi National Law University, Kharkiv, Ukraine.

${ }^{46} \mathrm{PhD}$ of Law, Yaroslav Mudryi National Law University, Kharkiv, Ukraine.

${ }^{47} \mathrm{PhD}$ of Law, docent, Criminal Law Department, Yaroslav Mudryi National Law University, Kharkiv, Ukraine.
} 


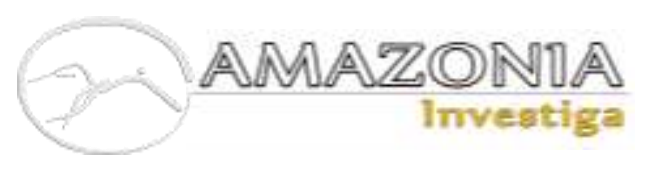

\section{Introduction}

Over the last decade, Ukraine has been trying to overcome the economic and financial crisis by reforming the entire state system of government, which ensures the economic development of our country. In the conditions of informatization of social processes and their globalization, the most important generally accepted approaches and movements of economic well-being of citizens are knowledge. The importance of knowledge for the development of the state and society is confirmed in the Association Agreement signed by Ukraine and the European Union, where in Art. 157 of Chapter 9, its purpose - to achieve an appropriate and effective level of protection and enforcement of intellectual property rights, and in Part 2 of Art. 159 states that the parties guarantee the protection of the legitimate interests of the owners of intellectual property rights. At the same time, the legal literature and mass media spread opinions about the insufficient level of legal protection of intellectual property by means of civil, administrative and criminal law, as well as about significant shortcomings of expert activity and litigation when considering and making appropriate decisions on intellectual property. The following negative conclusions and results of criminal proceedings are confirmed, with a small number of people convicted of abuse due to intellectual power. In 2018 under Art. 176 of the Criminal Code of Ukraine, which provides for criminal liability for infringement of copyright and related rights, 5 people were convicted under Art. 177 of the Criminal Code - 1 person, Art. 229 ("Illegal use of the mark for goods and services, brand name, qualified indication of the origin of goods") of the Criminal Code - 3 persons, and under Articles 231, 232 of the Criminal Code there are no convicts. Such statistics are acceptable for countries where counterfeit comrades of well-known companies are not openly sold, information that creates a commercial or banking commission that appears in Ukraine is not illegally collected or used. These data confirm the ineffectiveness of state measures for the legal protection of intellectual property and require their improvement at the state and scientific levels.

The relevance of the chosen topic is confirmed by the need for interdisciplinary study and analysis of the state of legal protection of intellectual property with the delineation and solution of key problems and finding the optimal model of such protection within the legal system of Ukraine.

\section{Bibliography review}

Analysis of recent research and publications. The issue of legal protection of intellectual property has been given sufficient attention for many years by scholars in various fields of law such as Alekseev (2007), Berzin (2009), Chuprova (2007), Demidova (2011), Diduk (2008), Fomin (2008), Kapitsa, Malchevskyi, Aralova, Fedchenko (2002), Karpukhina (2002), Kharchenko (2010), Kharytonova (2011), Latypov (2007), Likhova (2006), Mocherny \& Ustenko (2009), Radutny (2008), Yastrebov \& Grigorenko (2007).

Emphasizing the scientific value of the results of their research, we note that the legal literature still lacks interdisciplinary research on the problems of legal protection of intellectual property, insufficient coverage of the new view of property as an updated phenomenon and as an object of legal protection, which is a key issue optimal model of legal protection of intellectual property and its relationship with the protection of property in general. Such questions are the purpose and objectives of this scientific work.

\section{Methodology}

Methodological significance for the theoretical search for the optimal model of legal protection of intellectual property is the author's approach, which consists in conducting research from the point of view of public policy in various spheres of public administration, including crime control, within the legal system of Ukraine.

Taking this position, the research areas selected:

a) analysis of key state measures for the legal protection of intellectual property in the implementation of reforms in Ukraine;

b) consideration of the issue of intellectual property in such areas of law as civil, administrative and criminal, outlining the key issues of achieving the appropriate level of effectiveness of legal protection of this social value;

c) assessing the quality of the proceedings in the consideration of relevant intellectual property materials and the value of expertise and expertise. 


\section{Main discussions}

The main state measures for the legal protection of intellectual property in the implementation of reforms in Ukraine and their overall assessment. Such measures carried out at the state level during the last five years and are subject to consideration and analysis, which includes following:

a) enshrining in the the Constitution of Ukraine the European integration course of our country, which has already proclaimed the constitutional guarantee of intellectual property protection;

b) approval and partial implementation at the state level of the Sustainable Development Strategy "Ukraine 2020" (Order of the President of Ukraine of January 12, 2015 № 5/2015;

c) development and approval of the Concept of reforming the state system of legal protection of intellectual property in Ukraine by the order of the Cabinet of Ministers of Ukraine of June 1, 2016 № 402-r;

d) introduction of a new approach to the organization of proceedings in the field of intellectual property protection to create such a specialized court as the Supreme Court of Intellectual Property (Article 31 of the Law of Ukraine "On Judiciary and Status of Judges" of February 2, 2016 and Decree of the President of Ukraine "On the establishment of the Supreme Court of Intellectual Property" of September 29, 2017) and others.

For comparative analysis, we select government measures that have been implemented or are being implemented in the United States, France, Germany, China and other countries.

The general review of the given normative-legal acts allows to declare that in the aggregate the specified measures of the state level which are realized in Ukraine, we unquestionably promote purposefulness and orderliness of reforming of the state system of legal protection of intellectual property. At the same time we will analyze the ability of this system to perform its functions in modern conditions of informatization and globalization of social processes. Such functions include: defining and organizational (strategic and tactical), methodological, mobilization, resource, regulatory and other functions. In addition, in the analysis we take into account one of the main roles of intellectual property in society and the state - it is one of the most important engines of economic and financial development of the country and the achievement of wealth of citizens.

As a full-fledged subject of international relations in the field of intellectual property protection, our country is gradually fulfilling its commitments with the consolidation in the above-mentioned Sustainable Development Strategy "Ukraine 2020" of the priority of intellectual property protection reform (security vector). In order to implement this task, the Concept of Reforming the State System of Legal Protection of Intellectual Property in Ukraine confirms that the state system of legal protection of intellectual property has shown low efficiency in solving key tasks and inability to ensure the development of intellectual property as an important element of national innovation system and state economy. It was also noted that the imperfect and inert system of public administration in the field of legal protection of intellectual property has led to a lack of significant progress in adapting the legal framework to modern economic and political conditions (combating "patent trolling", Internet piracy, meeting IT needs -industries, militaryindustrial and agro-industrial complexes, etc.).

The main areas of implementation of the Concept are:

a) introduction of a transparent two-tier structure of the state system of legal protection of intellectual property, under which the Ministry of Economic Development ensures the formation and implementation of state policy in the field of intellectual property; policies in this area;

b) reorganization of the system of collective management of property copyrights and related rights;

c) improvement of national legislation and its harmonization with EU legislation, in particular, with amendments to the Criminal Code (hereinafter - the Criminal Code) of Ukraine and the Code of Ukraine on Administrative Offenses (hereinafter - the Code of Administrative Offenses), etc.

The defining state measures to improve the legal protection of intellectual property include the establishment of the Supreme Court on intellectual property as a higher specialized court (Article 31 of the Law of Ukraine "On the Judiciary and the Status of Judges" of February 2, 2016 and the decree of the President of Ukraine "On the establishment of the Supreme Court of Intellectual Property" of September 29, 2017). 


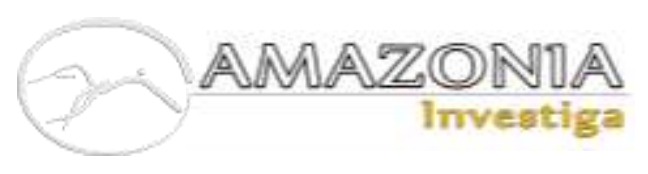

The analysis of the above state measures to reform the state system of intellectual property protection allows to express some considerations.

First, it should be recognized that concrete management steps are being taken at the state level to improve such a system, recognizing the priority of intellectual property protection reform over the security vector, which is a de facto recognition of the many threats to intellectual property, both internal and external. At the same time, it is doubtful that the Ukraine 2020 Sustainable Development Strategy refers such a reform exclusively to the security vector without mentioning it in relation to the development vector.

Secondly, we are critical of the limited main directions of the Concept of reforming the state system of legal protection of intellectual property in Ukraine, which do not include the protection of such property, carried out, for example, by law enforcement agencies and expert institutions coordinated by the Ministry of Internal Affairs.

Thirdly, the mentioned program documents do not pay attention to the need to create conditions for the training of specialists in the field of intellectual property protection, as is the case in China.

Fourth, given the specificity of the proceedings conducted by the Supreme Court of intellectual property, related to the need for a judge of such a court to have knowledge of intellectual property, we note that the presence of such knowledge is not recognized in Art. 33 of the Law of Ukraine "On the Judiciary and the Status of Judges" is a mandatory qualification requirement for a judge. At the same time, there is a positive experience of developed European countries (for example, Germany), which should be implemented in Ukraine. It is also necessary to clarify the powers of this judicial institution, namely, what materials of its proceedings are considered. In our view, given the knowledge that judges of the High Court of Intellectual Property must have, this court should hear all intellectual property cases, including criminal and administrative ones.

In general, these state measures should be aimed at a comprehensive solution to the problem of legal protection of intellectual property with increasing the level of professionalism in this area and legal awareness of ordinary citizens. However, they still need to be improved, taking into account the national interests and the interests of individual individuals and legal entities, the best foreign experience and international standards, which is confirmed by subsequent research results.

Theoretical and legislative problems of ensuring the effectiveness of legal protection of intellectual property.

We will consider this aspect of intellectual property on the example of such branches of law as civil, administrative and criminal, the rules of which create a legal basis for the protection of such property, implemented within the state system of legal protection of intellectual property. It is important that the accuracy and clarity of the meaning of "intellectual property" is a key criterion for building and achieving the effectiveness of such a system, assessing the level of enforcement of intellectual property rights and legitimate interests in them.

The concept of "intellectual property" is organically related to the concepts of "property" and "ownership of information", which are correctly recognized in the legal literature as interdisciplinary and, above all, civil law. However, neither the science of civil law nor civil law can still offer society a generally accepted understanding of these concepts and their relationship. This situation negatively affects the choice of a reasonable model of legal protection of intellectual property at the state level, which, depending on the concept of intellectual property and its relationship with property, can be of different types: (a) a separate state system of legal protection of intellectual property. in Ukraine) or (b) a subsystem in the unified state system of legal protection of property ownership or (c) another - as a component in the general state system of legal protection of property, where the subsystem is the legal protection of information, a component of which is legal protection of intellectual property. Decisive in this choice of model is to understand the meaning of "intellectual property". "Ownership of information and "property"and their relationship. Let's consider these concepts.

It is important that in modern conditions of informatization of social processes the concept of "property" has acquired a new meaning, which is not yet fully taken into account in the civil legislation of Ukraine. 
The essence of such a novella, which is increasingly recognized in scientific circles, is a conceptual departure only from the material (corporeal) understanding of property with the recognition of intellectual property and ownership of other information with limited access to property as a generic concept. It is no longer news that intellectual property is recognized by innovators as civilized property, economists refer to economic property (Borisov, I.V. Spasibo-Fateeva, V.L. Yarotskyi and others, 2011) and philosophers consider the type of ownership of information in rational and creative activities, which are characterized by innovative features and the concept of "priority" is essential (Demidova, 2011). Such features are recognized: 1) "superiority in time in carrying out any activity; 2) priority - a necessary condition for the issuance of a patent for an invention or recognition of scientific and technical achievements by discovery; is determined by the date of application or the first publication (Demidova, 2011).

As acknowledged by O.I. Kharytonova, in the field of intellectual property law in approaches to defining the concept and characteristics of intellectual property there is a tradition according to which jurists focus on the characteristics of intellectual property rights, sometimes with little characterization of "actual" (social, economic) intellectual property, while representatives of economics more carefully analyze the very concept of "intellectual property". However, as the scientist further emphasizes, the study of intellectual property from the point of view of economic theory has its own vulnerability, because they often make the concept of property excessively dependent on the things of the material world, in which property arises (Kharytonova, 2011). Considering the traditional approach to the understanding of property as the appropriation of means and products of production within and through a certain legal form, indicates that, although in the literature the concept of "property" is associated mainly with misappropriation, but there are no reasonable obstacles to apply other goods, including intangibles, calling it property in a broad (modernized) sense. Thus, as social relations concerning things and other tangible and intangible goods, in which some persons (owners) treat certain goods as their own, and all other persons (not owners) treat or should treat these same goods as others and should refrain from encroaching on these benefits (Kharytonova, 2011).

A broader understanding of property than as an attitude to material goods (corporeal things) is recognized by other well-known civilists. For example, S.S. Alekseev emphasizes the literal exact coordination of the main sources of intellectual products, other "creative" and related relationships with the defining features of the general concept of "property". According to the scientist, it is completely acceptable from a scientific and practical point of view to classify intellectual property objects as a specific kind of "things", as lawyers in ancient Roman jurisprudence did, choosing the term "disembodied thing" for this purpose. The scientist recognizes the relation of intellectual property as "full-blooded property" (Fomin, 2008). Thus, it is confirmed that in the modern conditions of informatization of social processes, property as an object of legal protection is an updated phenomenon that reflects the modernized content of the phenomenon of property.

In addition, the basis of this position is laid in the historical pre-revolutionary scientific works of prominent scientists. For example, I.Ya. Foynitsky acknowledged that among the property rights a special place is occupied by the "right of abstract property", which means a legal opportunity to benefit from the products of intellectual labor. According to the differences in the scope of such work, the right of abstracted (intellectual) property was divided into 1) copyright, which meant the right to benefit from the products of intellectual labor in science or art, and 2) the invention in the field of factory, factory, craft (Foynitsky, 1907). Thus, the scientist specifies that the subject of abstracted property is the form in which the thought is expressed, instead of the essence of thought (Foynitsky, 1907). Thus, it follows that he recognized "abstract property" (in the modern sense - intellectual property) as a kind of property with a special place among property rights. From our point of view, this is confirmed today with the difference that the subject is information that has a material expression.

An important argument for recognizing intellectual property as a type of property is contained in the documents of authoritative international institutions. Thus, the World Intellectual Property Organization considers the following types of property:

movable property, which consists of various things that move in space, such as a watch or car; real estate - land and objects that are constantly on it, such as a building; ownership of securities, such as currency, stocks, promissory notes, bonds;

intellectual property, the objects of which are the creation of the human mind, human intellect (WIPO Publication, 1998). 
However, in civil law, this position of the World Intellectual Property Organization on intellectual property as a type of property has not yet been implemented. In modern conditions, the Ukrainian legislator refers to the objects of intellectual property: literary and artistic works; computer programs; data compilation (database); implementation; phonograms, videograms, transfers (programs) of the organization of its speech; scientific discoveries; inventions, industrial designs; innovation proposals; trademarks (signs for goods, services); commercial (brand) names; trade secret and others (in Article 420 of the Civil Code (hereinafter - the Civil Code) of Ukraine provides an incomplete list of such objects) with distinctions from ownership of objects.

In Administrative Code, protection of intellectual property is carried out in its various chapters: Art. 51-2 "Violation of the rights to the object of intellectual property rights" in Chapter 6 "Administrative offenses encroaching on property", and Articles 164-3 ("Unfair competition"), which establishes administrative liability, in particular, for obtaining, use, disclosure of trade secrets, in Chapter 12 "Administrative Offenses in Trade, Catering, Services, Finance and Entrepreneurship." By choosing the place for Articles 51-2, the legislator confirms the recognition of intellectual property as a type of property.

Another situation is in criminal law, where intellectual property is not yet perceived in unity with property as an object of criminal law protection, but a material (bodily) approach to understanding the latter dominates. Thus, Articles 176, 177, 229, 231 and 232 of the Criminal Code of Ukraine, which establish liability for encroachment on intellectual property, are located in various sections of the Special Part of the Code outside its section VI "Crimes against property". However, in the system of legal regulation, intellectual property is already a specific type of such property, which should be reflected in modern criminal law. It should be borne in mind that intellectual property as a specific type of property permeates many spheres of public and state life in which intellectual activity is carried out, in particular, it includes the right to protection from unfair competition without restricting such a right to economic activity. national criminal law.

This follows, in particular, from Art. 2 of the Convention establishing the World Intellectual Property Organization $\mathrm{N}^{\circ}$ 995-169, signed in Stockholm on 14 July 1967 and amended on 02.10.1979 (WIPO Publication, 1998), which stipulates that "intellectual property" includes rights relating to: literary, artistic and scientific works; performing activities of artists, sound recordings, radio and television programs; inventions in all spheres of human activity; scientific discoveries; industrial designs; trademarks, service marks, brand names and commercial designations; protection against unfair competition, as well as other rights that are included in intellectual activity in the industrial, scientific, literary and artistic spheres.

Thus, we can confirm that in civil, administrative, and criminal law there are a number of issues regarding the introduction of a new understanding of the concept of "property", which in modern informatization of social processes reflects the already modernized nature of property as a phenomenon, as well as its relationship with the concept of intellectual property. "As" genus - species ".

Along with the problem of legislative consolidation of the perception of intellectual property as a type of property (as an object of legal protection), there is another recognized shortcoming in the field of legal protection of intellectual property rights - the inconsistency of individual laws with each other. Yes, Art. 25 of the Law of Ukraine "On breeding in animal husbandry" determines that the selection achievement in the field of breeding livestock is recognized as an invention. At the same time para. 1 item 3 of Art. 6 of the Law of Ukraine "On protection of rights to inventions and utility models" establishes that legal protection under this Law does not apply to plant varieties and animal breeds. When deciding on the affiliation of products to intellectual property should be based on the content of the general concept and structure of intellectual property (Karpukhina, 2002).

Some inconsistency of formulations of the given article and Art. 440 of the Civil Code of Ukraine, in which the right to use the work is not recognized as exclusive. In this regard, the legal literature rightly emphasizes the incorrectness of the text of the rules and emphasizes the need to recognize the right to use the work as exclusive in connection with the legal nature of this right (Kharchenko V.B., 2002). This undoubtedly has a negative impact on the quality and effectiveness of legal protection of intellectual property in relation to exclusive rights. 
Among the objects of intellectual property there is a trade secret (Article 505 of the Civil Code), the signs of which the authors recognize the following:

1) the information has commercial value;

2) information constituting a trade secret is not known to other persons and there is no free access to it on legal grounds;

3) measures have been taken to protect the confidentiality of information (Latypov I. A., 2007).

In our opinion, the content of these features allows to classify as a trade secret any secret (secret) information or other types of information with limited access, which has a value and can be a kind of product. A similar conclusion is made by A.G. Diduk, who believes that the concept of "trade secret" is broader in meaning than the concept of "intellectual property rights", and therefore not every trade secret or know-how should a priori be recognized as an object of intellectual property rights (Diduk, 2008).

These civil inconsistencies are because of information relations, which cover relations arising from intellectual property and other information, as well as elements of their structure are insufficiently defined and regulated by national and international law. A trade secret is an object of intellectual property because it is the result of a person's mental, intellectual activity, possibly in an interpreted form (the result of the application of technology, skills, abilities or technological process without human influence). The peculiarity of trade secrets (its mandatory feature) is that such information has commercial value and dissemination in the field of economic activity. It is a component or the most probable attribute of such activity.

Computer information is also an object of intellectual property. In modern conditions of development and dissemination of information space, computer information as a result of human mental activity acquires a new meaning - in relation to it there are, although specific, but still property rights to its possession, use and disposal, as well as personal non-property rights. This is due to the development of information technology, tools, methods that ensure the creation of information products, its distribution, preservation, transformation to meet the various needs of individuals, legal entities, local communities, the state. Computer information, which, acting as an intangible creative (intellectual) result of human labor, meets not only the needs of a particular person, social group, state, but in many cases is the object of legal and illegal public use with difficulty isolating, preventing criminal proliferation, processing or other use. It is already in circulation in civil law, and as a commodity - in economic and legal turnover, in addition, in many cases acts as a means of creating capital, influencing political, social, economic and other processes in the state and the world. Despite such social and economic significance, there is no unambiguous legal interpretation of such information. This is typical of foreign legislation, where as a similar concept is more often used, for example, in Austria, Canada, Finland, Germany, Holland - "data", in Poland - "record", and in Japan - "electromagnetic record" (Likhova, 2006).

Computer information with the rights to it becomes an intangible (disembodied) object of property relations. Such information is perceived only by automated equipment and is data in a form suitable for automated processing by means of such equipment.

In the legal literature there is a proposal to distinguish such a feature of information as its fixation on a tangible medium. Analyzing the above approaches, D.A Yastrebov and S.V. Grigorenko rightly points out that based on this understanding, computer information that is in the network, in the radio and electromagnetic field, is without proper legal protection and protection, so its manipulation is not criminally punishable. Researchers propose to define computer information as such information that is recorded on a computer medium or transmitted by telecommunication channels in a form accessible to computer perception. Such a proposal should be accepted (Yastrebov \& Grigorenko, 2007).

In addition, we consider the position of researchers, who point to the need to recognize certain components of a computer program as the object of copyright, and the characteristics of these components of this program still need to be substantiated.

As you know, the term "information" covers not only intellectual property, but also other information about which there are rights to own, use and dispose of it. Examples of such information are types of classified and other information with limited access, confidential information that is not considered intellectual property. A common feature of such information is that it is not public and property rights arise in relation 


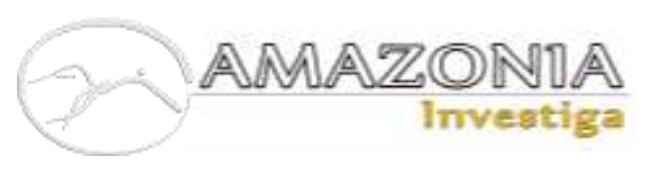

to it, as well as such information is in the plane of legal regulation, in particular administrative law and criminal law.

The objects of intellectual property rights can only be intangible objects - things that in Roman private law were called incorporeal. Such objects are ideas, images, symbols, thoughts, hypotheses, and so on. These objects can become intellectual property only if they are able to materialize, to be embodied in material media. An idea that is not capable of such materialization does not become an object of intellectual property rights;

4) the ability of the object of intellectual property to replicate, in contrast to the material objects of property. However, the intellectual property right is established and acts only in relation to this intangible thing (idea, image, symbol, combination of sounds, etc.), and not in relation to the material media in which the author's idea is embodied. The owners of material media, in which the objects of intellectual property are embodied, will be other persons who have purchased such media on a legal basis (Yastrebov \& Grigorenko, 2007).

Indeed, the right to a thing (bodily) and to an object of intellectual property and other information have significant differences, but their common feature is that they express the authority of the subject in relation to a particular social (tangible or intangible) good that is the result of activity man. The right to a thing (corporeal) is property. Intellectual property rights consist or may consist of personal property and personal non-property rights.

The property rights of an intellectual property subject are those rights that represent a certain property interest for him, i.e. they derive a legal property benefit. In intellectual property law, the property rights of the creator and his heirs prevail over all his other rights.

According to Art. 41 of the Constitution of Ukraine, the subject of intellectual property rights has the right to own, use and dispose of the results of their intellectual and creative activities. This means that he has the right to keep these results behind, to freely exercise his legal influence on this property. Property rights of this type of property are recognized as goods and may be put into civil circulation in any manner not prohibited by law.

According to Part 1 of Art. 423 of the Civil Code of Ukraine personal intangible intellectual property rights are: 1) the right to recognize a person as the creator (author, performer, inventor, etc.) of the object of intellectual property rights; 2) the right to prevent any encroachment on the intellectual property right, capable of damaging the honor or reputation of the creator of the object of intellectual property rights; 3 ) other personal intangible intellectual property rights established by law.

Property rights in the real (body sense) - property (real) rights; ownership of intellectual property can be in the form of a special set of property and non-property rights. At the same time, property rights (in the physical sense) and property rights to information, in particular intellectual property, are varieties of such a modern legal phenomenon as property rights (in the broadest sense).

Thus, property as a renewed phenomenon is a set of material and / or related intangible relations that arise in connection with things and a certain form of their appropriation, which permeate many spheres of public and state life and are generated by the development of productive forces. Including the objects of property (objects of relevant social relations) should include intellectual property, other information (information products), money and certain other things.

Let's take a brief look at the achievements of some foreign countries in the field of legal protection of intellectual property, in particular, its relationship with property. Thus, the right of ownership is recognized in the Statute of Queen Anne of 1709 - the first law on copyright, if we do not take into account the statute of monopolies, where an attempt was made to regulate intellectual property. This law confirmed the author's right to print and publish his works, which could be transferred to a bookseller for a fee. This legal act also protected against unauthorized copying of published works, which reduced the income of the right holder (Mocherny \& Ustenko, 2009). 
We are also very interested in the experience of China, which is carrying out real economic reforms. The legislation of this state is based on the existence at the present stage of information economy and knowledge economy, considers new technologies, information, intellectual property as a commodity in the production market, the circulation of which is regulated primarily by property legislation (Lee, 2001).

The protection of intellectual property in the United States was carried out by the first copyright laws before the French and American revolutions. The Massachusetts law of March 17, 1789 stated that "there is no property that belongs to a person more than that which is the result of his mental labor" (Likhova S. Y., 2006).

In developed countries, a different attitude to the fixation and protection of intellectual property and other information, although the level of regulation no longer satisfies well-known scientists. In this regard, the statement of the French theorist of law Jean-Louis Bergel, who states the crisis of jurisdiction that has arisen in international civil society in connection with the globalization of information processes that are ahead of the state, especially in the economic sphere and in private life, is indicative (Likhova S. Y., 2006).

Recognition of information as an object of property and a component of property as an object of administrative and criminal protection is only the first step towards recognizing real social relations, which are constantly violated by illegal actions with the task of enormous damage. The purpose of this direction of state policy should be to strengthen the independence of our country in the information space with the gradual and dynamic introduction of new mechanisms for the protection of property as a social, economic and legal basis for state sovereignty.

The quality of legal proceedings in the consideration of relevant materials on intellectual property and the importance of special knowledge and expertise as an indicator of the need to improve the state system of legal protection of intellectual property.

The problem of investigative and judicial practice and ensuring proper protection of the rights of the victim is the establishment of damage in the qualification of wrongful acts, which is recognized by the legislator as a constructive feature, or such damage is a kind of other consequence of an administrative or criminal offense. Damage is established for property (things or their combination) and property rights (for tangible - tangible objects in the modern civil law sense and intangible - intellectual property, other information), which suffered because of administrative or criminal encroachment.

To clarify the range of such issues, first, a survey of practitioners of the prosecutor's office, the Security Service, the police (220 respondents) was conducted. To the question: "Does it cause difficulties in your professional activity to establish harm in the qualification of administrative or criminal offenses?" $75 \%$ of respondents gave a positive answer - investigative bodies of the Ministry of Internal Affairs (city and regional level) and prosecutors (district and regional level). Among the list of questions that cause difficulties, the largest number of positive answers were received:

1) the application of regulations governing the assessment of property and property rights and require special knowledge - $45 \%$ of the total number of respondents (of which: for objects intellectual property - 64\%, property rights to other objects of property - 42\%; other cases - 26\%);

2) establishing the structure and amount of property damage - 33\%, for the following reasons: if such a constructive feature of the offense (administrative or criminal) in respect of intellectual property reflects the concept of valuation - 41\%; inaccuracy of determination in Administrative Code and Criminal Code of a consequence of the considered offenses in the form of property damage or other consequence with such kind - 62\%; lack of unambiguous definition of the structure of damage and property damage as a criminal consequence in theory - 56\%, legislation - 85\%); inconsistency of the date of examination or assessment of property and time of the crime - 53\%; other reasons - 32\%.

Indeed, in classifying crimes, the investigator, the prosecutor, and then the court must have the ability to work with the legal framework (documents) and apply not only professional legal knowledge, but also special, albeit limited. Without such knowledge it is impossible, in particular, to correctly formulate the questions for the examination, to assess the reliability and completeness of the expert's report, the act of property valuation. 
When establishing damage in the process of qualification of an administrative or criminal offense, a number of regulations governing the valuation of property and property rights are applied, which can be divided into: a) general: Law of Ukraine "On property valuation, property rights and professional appraisal activity in Ukraine "№ 2658-III of 12.07.2001, Resolution of the Cabinet of Ministers of Ukraine (hereinafter CMU)" On approval of the National Standard № 1 "General principles of property valuation and property rights" № 1440 of 10.09.2003 and b) special, ie those used in determining the damage as a consequence of certain crimes, for example, the resolution of the Cabinet of Ministers "On approval of the Procedure for determining the amount of damage from theft, shortage, destruction (damage) of property" № 116 from 22.01.1996, approval of the National Standard № 4 "Valuation of intellectual property rights" № 1185 of 03.10.2007, the order of the State Property Fund of Ukraine "On approval of the Methodology for the assessment of intellectual property rights "dated 25.06.2008 № 740, etc.

As stated, first, law enforcement and judicial officials note the difficulty of establishing the value of infringed property rights to intellectual property in the classification of crimes under Articles 176, 177, 231, 232 of the Criminal Code. Regarding Articles 231, 232 of the Criminal Code, this issue was considered in depth by P.S. Berzin with interpretation and analysis of the provisions of the National Standard № 4 "Valuation of intellectual property rights", approved by the Cabinet of Ministers of 03.10.2007 № 1185, and the Methodology of valuation of intellectual property rights, approved by the order of the State Property Fund of Ukraine from June 26, 2008 № 740 (Radutny, 2008). The scientist concluded about the expediency of using three approaches to calculating the amount of damage in the composition of the crimes under consideration - income, expenditure and comparative. Each of these approaches, in his opinion, is based on their own, normatively defined methods of assessing the damage caused by the violation of the rights to a certain object of intellectual property rights (including commercial and banking secrecy).

With regard to trade secrets and other intellectual property, there is no doubt about the correctness of the application of these regulations to determine the amount of infringed property rights, because their provisions apply only to intellectual property, which is a trade secret. Banking secret, although not public information, but is not an object of intellectual property, and trade secret can be only part of such information (Radutny, 2008), if, for example, the bank's management recognizes as a trade secret the codes used by banks to protect information and / or the security system of banks and customers. Banking secrecy in its content (volume) has different legal regimes depending on the purpose: the regime of open information; trade secret regime and bank secrecy regime (Dzera, Kuznetsova \& Luts, 2006). For example, according to Art. 60 of the Law of Ukraine "On Banks and Banking" banking secrecy includes information on the activities and financial condition of the client, which became known to the bank in the process of customer service and relationships with him or third parties in providing bank services, in particular, on the financial and economic condition of the client, information on the organizational and legal structure of the legal entity-client, its leaders, activities. Such information may include constituent documents; documents that allow to engage in business or economic activities and its individual types; information on all established forms of state reporting; documents on solvency, which in accordance with the resolution of the Cabinet of Ministers "On the list of information that does not constitute a trade secret" of August 9, 1993 № 611 can not be recognized as a trade secret. At the same time, such information as a component of bank secrecy is a kind of secret information (Articles 6, 8 of the Law of Ukraine "On Access to Public Information") with a mandatory feature - limited access to it. Thus, bank secrecy is defined as confidential information with a reflection of all its components, so to establish the value of infringed property rights to such an object has a separate method, which would take into account all the nuances of this type of information with limited access. A similar approach is used to establish the value of infringed property rights in relation to insider information (Article 232-1 of the Criminal Code) and information about the issuer (Article 232-2 of the Criminal Code), which are also information with limited access if there are appropriate grounds. Unfortunately, today there are no special methods for establishing the value of violated property rights in relation to such information.

Based on the above, we recommend establishing the value of property rights in the part that is not the object of intellectual property, according to the rules defined by the National Standard № 1 "General principles of property and property rights valuation", approved by the Cabinet of Ministers of September 10, 2003. № 1440. In this document, property rights are recognized as the object of assessment in intangible form (paragraph 3 of the Standard). 
The peculiarity of such an assessment is the possibility of choosing to establish not only the market but also the non-market value of property rights violated by the crime as the object of assessment. Non-market types include replacement cost, reproduction cost, residual replacement cost (reproduction), value in use, consumer value, liquidation cost, investment value, special value, liquidation value, net realizable value, estimated value and other types, the procedure for determining which is established separate national standards (item 19). Yes, the determination of the value in use is to evaluate the object of evaluation without considering the principle of the most efficient use. The cost in use is determined for the objects of assessment, for which further use is planned in a specific planned or existing way.

Another problem is the date of the damage caused by the illegal infringement of limited information rights intellectual property: in the qualification of the offense and the expert assessment, which in many cases do not coincide in time. This, first, shows the problem of adequacy of the expert value of infringed rights to an intellectual property object or other object in intangible form - information, and the value of infringed rights, which is established by the investigator amendments made by the Law of Ukraine to the Criminal Code of Ukraine, which come into force on January 1, 2020), as well as the investigator, the prosecutor when qualifying the offense at the time of the offense.

Clause 26 of the National Standard № 4 "Valuation of Intellectual Property Rights", approved by the Resolution of the Cabinet of Ministers of October 3, 2007 № 1185, stipulates that the amount of damages for illegal use of intellectual property is determined as of the valuation date using the valuation procedures for the accumulation of profit (income), which was not received by the subject of intellectual property rights and / or the licensee due to improper use of the object of intellectual property rights, based on the volume of production and / or sales of counterfeit products. This means that in the relevant act (conclusion) the amount of damage caused by illegal use of intellectual property is set on the date of assessment, which obviously does not coincide with the time of the act and the occurrence of socially dangerous consequences in the form of damage. The structure and amount of damages specified in the appraisal report covers not only the losses caused, but also the failure of the victims to pay due, so the investigator and / or prosecutor must independently calculate the amount of property damage caused by the crime, Thus the last can be taken into account by the investigator, the prosecutor or the judge at qualification of the crime provided by Art. 176 of the Criminal Code, in whole or in part, depending on many circumstances that characterize the crime, in particular, the direction of intent of the perpetrator, the extent of illegal reproduction, the sale of intellectual property. A similar situation, considering property damage in the qualification of infringements of other intellectual property (Articles 177, 229 of the Criminal Code), other information with limited access (Article 231 (on banking secrecy), which confirms the proximity, not the exact size property damage caused by the crime.

The solution to this problem is possible by improving the methods of assessing the damage caused by the infringement of intellectual property and other information with limited access, including those classified by law as intangible assets. However, we should agree with scholars who point out that intangible assets are by nature a special type of asset that cannot be measured using traditional approaches to real estate and movable property. In addition, it is unrealistic to develop a universal methodology for valuing intangible assets. This is primarily because these assets, in particular, are heterogeneous in composition, nature of use or operation in the production process and have varying degrees of impact on the financial condition and results of economic activity of the enterprise (Yastrebov D.A., Grigorenko S.V., 2007). At the same time, given the importance of establishing a scientifically sound value of intangible assets, it is advisable to improve the relevant expert methods.

World experience confirms the complexity of this issue in both theoretical and practical terms and the need to involve more sophisticated methods and other methodological tools in calculating the value, especially of intellectual objects, as well as other information.

\section{Conclusions}

Establishment and review of problematic issues of legal protection of intellectual property in modern conditions of informatization and globalization of social processes and the choice of approaches to modeling possible options for building a state system of such protection allows us to formulate the following conclusions: 
1. Determining in the development of a new state system of legal protection in relation to intellectual property should be a renewed understanding of the concept of "property" - a set of material and / or related intangible relations that arise in connection with things and a certain form of their appropriation. spheres of public and state life and generated by the development of productive forces. Including the objects of property (objects of relevant social relations) should include intellectual property, other information (information products), money and certain other things.

2. Creation of a perfect state system of legal protection of intellectual property should be carried out with the preliminary development and further implementation of the General concept of legal protection of property with its subsystems such as (a) property (set of things), property rights and property obligations to them (b) intellectual property and (c) ownership of other information. At the same time, it is expedient to envisage a single codified legislative act (Code) on property, which should cover the issues of substantive, procedural law, as well as judicial proceedings.

3. The effectiveness of the system of legal protection of intellectual property can be ensured only in a comprehensive way with the introduction of three-stage reforms: at the first stage of the reform should be implemented by creating a state system of intellectual property protection (as it is implemented in Ukraine now); at the second stage - with the creation of a single state system of legal protection of information, where the subsystems are legal protection of (a) intellectual property and (b) other information, and at the third final stage should create a single general state system of legal protection of property with subsystems things, (b) intellectual property, (c) other information. This approach to modeling options for legal protection of intellectual property at different stages of reforms will facilitate the implementation of systemic and comprehensive approaches that will ensure the proper effectiveness of these measures, in particular, take into account the specifics of intellectual property, provide for government decisions, including legal regulation judicial institutions, training of specialists taking into account the specifics of different types of property and, first of all, intellectual property and other information with limited access, raising the level of legal awareness of citizens.

4. It is necessary to develop or improve methods of assessment of intellectual property and other information with limited access, as well as to replenish special knowledge about such objects, considering the experience of developed countries and the level of technical progress not only in Ukraine but also in the world.

This article is an attempt to convey to readers the author's vision of possible options for state measures for the legal protection of intellectual property. Given the importance of intellectual property for the economic development of Ukraine, it is advisable to continue scientific research in this direction.

\section{The references}

Alekseev, S.S. (2007). Property law: problems of theory. Moscow: Norma. 2007. 240 p.

Bergel, J.L. (2000). General theory of law. Moscow: Nota Bene, 756.

Berzin, P.S. (2009). Criminal consequences: the concept, the main types, criminal and legal significance: a monograph. Kyiv: Dakor, 736 p.

Borisov, V.I., Spasibo-Fateeva, I.V., \& Yarotskyi, V.L. (2011). Civil law: textbook: in 2 volumes. Kharkiv: Pravo, T. 1.656 p.

Chuprova, E.V. (2007). Responsibility for economic crimes under the criminal law of England. Moscow: Walters Clover. 208 p.

Convention establishing the World Intellectual Property Organization N ${ }^{\circ}$ 995_169. Verkhovna Rada of Ukraine (signed in Stockholm on 14 July 1967 and amended on 2 October 1979). Available at: http://zakon3.rada.gov.ua/laws/show/995_169

Demidova, L.M. (2011). Property as an object of criminal law protection. Law of Ukraine, № 2, 242-248 p.

Diduk, A.G. (2008). Legal regime of confidential information: civil law aspect: author's ref. (dis. ... Cand. jurid. Science). Computer Science Academy of Ukraine, Kharkiv. 24 p.

Dzera, O.V., Kuznetsova, N.S., \& Luts, V.V. (2005). Scientific and practical commentary on the Civil Code of Ukraine: in 2 volumes. Kyiv. Urinkom Inter. T. 1. 832 p.

Fomin, G.F. (2008). Banking Law of Ukraine. Kharkiv. 330 p.

Foynitsky, I.Y. (1907). The course of criminal law. Part Special. Personal and property encroachments. St. Petersburg. 400 p.

Kapitsa, Y., Malchevskyi, I., Aralova, L., \& Fedchenko, L. (2002). Estimation of value of intellectual value in the scientific organizations. Bulletin of the National Academy of Sciences of Ukraine, № 7, 38-45 p. 
Karpukhina, S.I. (2002). Protection of intellectual property and patent science: a textbook. Moscow: Center for Economics and Marketing. 400 p.

Kharchenko, V.B. (2010). Variety of plants and animal breeds as objects of intellectual property law and categories of criminal law. Bulletin of Kharkiv National University named after V.N. Karazina. Law, № 929, 380 p.

Kharytonova, O.I. (2011). Introduction to the course "Intellectual Property Law": lecture. Law of Ukraine, № 3, 311-322 p.

Latypov, I.A. (2007). Ownership of information as a socio-philosophical problem: a monograph. Izhevsk, Udmur University, $228 \mathrm{p}$.

Law № 1402-VIII. On the Judiciary and the Status of Judges: Law of Ukraine of 02.02.2016, Available at: https://zakon.rada.gov.ua/laws/show/1402-19

Law № 1440. On approval of the National Standard № 1 "General principles of property valuation and property rights": Resolution of the Cabinet. Ministers of Ukraine dated September 10, 2003. Official Gazette of Ukraine. № 37.

Law № 299/2017. On the establishment of the Supreme Court of Intellectual Property: Decree of the President of Ukraine of 29.09. 2017. URL: https://zakon.rada.gov.ua/laws/show/299/2017

Law № 402-r. On approval of the Concept of reforming the state system of legal protection of intellectual property in Ukraine: order of the Cabinet of Ministers of Ukraine dated 01.06.2016, Available at: https://zakon.rada.gov.ua/laws/show/402-2016-\%D1\%80

Law № 5/2015. On the Sustainable Development Strategy of Ukraine 2020: Decree of the President of Ukraine of 12.01.2015. Available at: https://zakon.rada.gov.ua/laws/show/5/2015\#n10

Lee, T. (2001). Search for directions of reform and openness policy. Beijing, Vol. 2. Reflections on the knowledge economy. $593 \mathrm{p}$.

Likhova, S. Y. (2006). Crimes in the field of realization of public, political and social rights and freedoms of man and citizen (section 5 of the Special Part of the Criminal Code of Ukraine). Kyiv. 573 p.

Mocherny, S.V., \& Ustenko, O.A. (2009). Fundamentals of economic theory: a textbook. 3rd ed., P. Kyiv: Academy, $504 \mathrm{p}$.

Radutny, O.E. (2008). Criminal liability for illegal collection, use and disclosure of information constituting a trade or banking secret. Monograph Kharkiv. Xylon. 202 p.

WIPO Publication (1998). Introduction to intellectual property. № 438 (R). Geneva: WIPO Pub. 652 p.

Yastrebov, D.A., \& Grigorenko, S.V. (2007). Legal issues of information security (criminal liability for crimes in the field of computer information in the Russian Federation). Moscow: Prima Press. 76 p. 